\title{
SINTAKTIČKE RAZLIKE IZMEĐU GLAGOLJIČKOGA I ĆIRILIČKOGA IZDANJA HRVATSKOGA PROTESTANTSKOG PRIJEVODA NOVOGA TESTAMENTA
}

\begin{abstract}
Hrvatski protestantski prijevod Novoga zavjeta izazivao je u hrvatskoj filologiji dosad najviše zanimanja zbog uočenih bitnih razlika u jezičnoj koncepciji njegova glagoljičkoga i ćiriličkoga izdanja, što ga razlikuje od drugih hrvatskih izdanja iz uraške tiskare. Najveći zahvati zabilježeni su pritom na razini grafije, glasova i leksika, čemu su hrvatski protestanti i sami pridavali najviše pozornosti, kako doznajemo iz brojnih predgovora njihovim objavljenim izdanjima. Premda nisu ni približno brojne kao razlike na drugim jezičnim razinama, zanimljive su i sintaktičke razlike između glagoljičkoga i ćiriličkoga Novoga testamenta (1562./1563.). Upravo se one u ovome radu raščlanjuju kao prilog boljemu poznavanju sintakse hrvatskih protestantskih izdanja.
\end{abstract}

Ključne riječi: reformacija, hrvatski protestantizam, 16. stoljeće, Biblija, Novi zavjet, hrvatski prijevod, sintaksa

\section{UVOD}

Predgovori izdanjima hrvatskih protestanata svjedoče o njihovoj velikoj brizi za točnost prijevoda i jezičnu razumljivost, što se može zamijetiti već u dvjema protestantskim početnicama, a zatim pratiti i u kasnijim izdanjima uraške tiskare. Kako čitamo u predgovoru Tabli za dicu (1561.), jezična razumljivost nastoji se pritom osigurati ponajprije dobrim leksičkim odabirom, a ocjena je li taj odabir bio uspješan prepušta se čitateljima. ${ }^{1} \mathrm{U}$ hrvatskome

$\overline{1}$ Usp. [...] ako va tih dviju kńižicah [knižicah] koju rič ili slovo krivo postavleno [postavleno] naidete, daite nam u Božjei ljubavi na znanje, hoĉemo potom popraviti (navedeno prema DAMJANOVIĆ 2007: 53). U primjerima koji se navode u ovome radu donosim transliteriran glagoljički tekst, a u uglatoj zagradi navodim razlike iz ćiriličkoga izdanja. Transliteracij- 
predgovoru glagoljičkomu izdanju Katekizma (1561.) Stipan Konzul obraća se čitateljima moleći ih da blagonaklono pristupe njihovu prvomu prijevodu te da ih upozore na ko pomanjkanje u tlmačenju, u besedah ili u slověh $v$ ortografiji kako bi takvi propusti mogli biti ispravljeni u sljedećim izdanjima koja planiraju tiskati, a među prvima najavljuje objavljivanje prijevoda $\mathrm{No}$ voga testamenta glagoljicom i ćirilicom (BUČAR; FANCEV 1938: 57-58). ${ }^{2}$ U njemačkome predgovoru istomu izdanju Primož Trubar obraća se kralju Maksimilijanu II. sa sličnom molbom, pozivajući ga da taj prijevod da ispitati stručnjacima (poznavateljima) hrvatskoga jezika radi utvrđivanja ima li »pogrešaka u riječima ili ortografiji« (BUČAR; FANCEV 1938: 58). ${ }^{3}$ Tako je i u hrvatskome predgovoru ćiriličkomu izdanju Katekizma (1561.) (BUČAR; FANCEV 1938: 63). ${ }^{4}$

Predgovor Novomu testamentu (1562./1563.) najbolje je poznat i najviše citiran u dosadašnjoj literaturi. U njemu se Antun Dalmatin i Stipan Konzul osvrću na prethodne liturgijske priručnike, ističući da ne postoji cjelovita Biblija na hrvatskome jeziku, već samo u dijelovima, i to u (hrvatskoglagoljskim) misalima i brevijarima, gdje niti dolaze pravim redom (križem', $i$ zmêšano postavleni) niti su ispravno prevedeni (ti isti kusi nisu povsuda ni pravo ni razumno stumaćeni) (NT1: 4). Zbog toga su započeli s prijevodom Novoga zavjeta iz'naibolega Latinskoga, Vlaškoga ${ }^{5}$ Nemškoga, i Kranjskoga

ska načela razlikuju se s obzirom na izvor iz kojega navodim primjere, ali citati se vjerno prenose kako ih zapisuju pojedini autori. Jedina je iznimka bilježenje slova $l$ i $n$ s natpisanom crticom u primjerima iz Table za dicu, gdje zbog tehničkih razloga odstupam u slijeđenju predloška označavajući palatalnost kosom crticom umjesto vodoravne.

2 Mi Vas prosimo, da ovo naše prvo delo tumačenje štampano od nas, sada za dobro vazmite $i$ na bolše obraćajući i tomačeći razumiete. I ako je u nem ko pomanjkanje u tlmačenju, u besedah ili u slověh v ortografiji, to isto nam skoro dajte u pravoj ljubavi na znanje. Hoćemo te iste za naprvo u drugih knigah popraviti. (Navedeno prema BUČAR; FANCEV 1938: 57).

3 Naša je molba, da ovu našu dobro mišljenu dedikaciju i knjigu dobrostivo primite, te da je od strukovnjaka hrvatskog jezika izvolite dati ispitati i nam javiti, ako imade pogrešaka u riječima ili ortografiji. (Navedeno prema BUČAR; FANCEV 1938: 58).

4 Toga radi vas prosimo ako bi u ovih knižicah ko slovo ili koja rič kriva ili nerazumna, dajte nam to prigodno z redom, s prave krstijanske ljubave na znanje, da se budemo znati za naprvo pobolšati [...] (navedeno prema BUČAR; FANCEV 1938: 63).

5 Koliko mi je poznato, dosad nitko nije istražio moguće talijanske uzore i predloške hrvatskomu protestantskom prijevodu Novoga zavjeta. Ivan Polovič usporedio je prijevod hrvatskih protestanata s talijanskom Biblijom tiskanom 1546. u Mlecima, no nije pronašao nikakvih podudarnosti te smatra da bi eventualna usporedba s kojom talijanskom protestantskom Biblijom možda bila plodonosnija (POLOVIČ 1908: 72). Istaknimo ovdje da su u nastanku najstarijih hrvatskih lekcionara 15. i 16. stoljeća, kako Vuk-Tadija Barbarić uvjerljivo i argumentirano pokazuje u svojim sustavnim istraživanjima toga korpusa, upravo talijanski predlošci (ili svjedoci, kako ih naziva autor) odigrali važnu ulogu, što je posebice vidljivo u Zadarskome i Ranjininu lekcionaru (BARBARIĆ 2015.a; 2015.b; 2016; 2017). 
tl'mačenja, u Hr'vacki jesik (NT1: 6). Svjesni da bi odabrana književnojezična osnovica mogla naići na neodobravanje, obrazlažu zašto su u svojemu djelu priproste, navadne razumne, obćene, vsagdanje, sadašnega vrêmena besede, koie Hr'vatê, Dalmatini, i drugi Slovenci, i Kranjci naiveće va njih govorenju govore, hotêli postaviti (NT1: 7), odstupajući pritom svjesno i namjerno od stanja zatečena u misalima i brevijarima, gdje je $v$ dosta Mestih' [...] pismenim 'načinom (kako niki prave) pisano ili nikim 'tuim 'nerazumnim ' jazikom' kako sami znate, i nêkude krivo tl'mačeno (NT1: 8). ${ }^{6}$ Predgovor završava uobičajenom molbom čitateljima da ih upozore na pogreške kako bi ih mogli ispraviti i na taj način poboljšati prijevod.

Nakon objavljivanja prvoga dijela glagoljičkoga izdanja Novoga testamenta počele su se javljati sumnje u ispravnost prijevoda. Primož Trubar u svojemu pismu iz Ljubljane Ivanu Ungnadu 19. srpnja 1562. piše kako je u Katekizmu i Novom zavjetu viel falsch prevedeno i otisnuto, no ne obrazlaže dalje svoju tvrdnju (JEMBRIH 2007.b: 63). Njegova tvrdnja pokrenula je bogatu korespondenciju jer je Ungnad htio doznati koliko u njoj ima istine, a Konzul obraniti prevodilačku djelatnost kojoj je bio na čelu. Zahvaljujući tomu danas raspolažemo brojnim svjedočanstvima o tome kako su na jezik prvoga hrvatskoga cjelovitog prijevoda Novoga zavjeta gledali ne samo hrvatski protestanti već i njihovi suvremenici. Većina prigovora odnosi se na odabranu pravopisnu praksu, loš leksički odabir i brojnost tiskarskih pogrešaka, dok oni koji izdanja brane redovito ističu kako su rabljene razumljive, »čiste« i "prave « hrvatske riječi, predlažući tek pomniju korekturu kako bi se smanjio broj pravopisnih i tiskarskih pogrešaka; ispravnost prijevoda, odnosno vjerno prenošenje smisla, načelno ni jedni ni drugi nisu dovodili u pitanje (v. više u FANCEV 1916.a: 150-153; JEMBRIH 2007.b: 41-43, 63-70).

Franjo Fancev smatra da je povod raspravi o ispravnosti prvih hrvatskih protestantskih izdanja bilo preveliko udaljavanje jezika od dotadašnje hrvatske liturgijske tradicije, odnosno provedenim ponarodnjavanjem »povrijeđena crkvena jezična predaja«, što objašnjava razliku u književnojezičnome oblikovanju i recepciji ranijih i kasnijih izdanja (FANCEV 1916.a: 159). ${ }^{7}$ Prema

${ }^{6}$ U hrvatskoj glagoljskoj knjizi 16. stoljeća, čijim su dijelom i djela hrvatskih protestantskih pisaca, supostoji više različitih književnojezičnih koncepcija, koje se razlikuju s obzirom na odabranu osnovicu. O složenoj hrvatskoj lingvističkoj i sociolingvističkoj situaciji u 16. stoljeću v. više u tekstovima objavljenima u BIČANIĆ 2011 te u MIHALJEVIĆ 2010.

7 Ovdje nije naodmet upozoriti na to da smo još daleko od sustavna i slojevita uvida u razmjere utjecaja glagoljaške književnojezične tradicije, koji su zamjetni već u ranim izdanjima hrvatskih protestanata i koje će buduća istraživanja nesumnjivo otkrivati ne samo na jezičnoj nego i na tekstnoj razini. S jedne strane možemo kao primjer utjecaja hrvatskoglagoljske tradicije na razini teksta spomenuti da glagoljičko izdanje Katekizma sadrži »tekst 'Simbol 
Fancevu, proces jezičnoga uređivanja kasnijih izdanja prema tradiranomu liturgijskom jeziku ${ }^{8}$ potaknut neodobravanjem hrvatskoga glagoljaškog svećenstva osobito se dobro ogleda u razlikama između glagoljičkoga i ćiriličkoga izdanja Novoga testamenta, koje nisu nimalo slučajne: ${ }^{9}$ promjene u ćiriličkome izdanju posljedica su naslanjanja na starije crkvene prijevode (FANCEV 1916.a: 158) ${ }^{10}$ Slažući se s Fancevljevom pretpostavkom da je promjena njihovih jezičnih stavova nastupila uslijed kritika zbog prevelika udaljavanja od hrvatskoglagoljskih biblijskih tekstova, Stjepan Damjanović ukazuje na to da su hrvatski protestanti pokazivali nesigurnost i prije objavljivanja ćiriličkoga izdanja, o čemu dobro svjedoče izmjene što se traže na fonološkoj i morfološkoj razini na korekturnome arku koji se odnosi na prvi dio glagoljičkoga izdanja (DAMJANOVIĆ 2014: 65-66, 112-129, 138-139). ${ }^{11}$

i spoznanje vjere' po svetom Atanasiju [...], koji se ne nalazi u Trubarovim katekizmima i abecedarijima, ali se nalazi u glagoljskim brevijarima kao 'Pěsan svete troice'." (ČUPKOVIĆ 2010.a: 211). S druge strane njezin je utjecaj na razini jezika vidljiv primjerice u čuvanju pojedinih naslijeđenih sintaktičkih obrazaca kada se radi o participima, čijom uporabom nerijetko odstupaju od slovenskoga predloška prilikom inače načelno dosljedna prevođenja Artikula prema Trubarovu izdanju (ETEROVIĆ 2016).

${ }^{8}$ Tradirani je liturgijski jezik bio hrvatski staroslavenski/hrvatskostaroslavenski/hrvatski crkvenoslavenski, kojim su tijekom hrvatskoga srednjovjekovlja i ranoga novovjekovlja bile pisane u prvome redu hrvatskoglagoljske liturgijske knjige (misali i brevijari).

${ }^{9}$ Gordana Čupković hrvatskim staroslavenskim utjecajima određuje pojedina grafijska i leksička rješenja, ističući da su brojnija u ćiriličkome izdanju (ČUPKOVIĆ 2013: 138-139). U svjetlu povratka knjiškim rješenjima zanimljivo je stoga vidjeti je li i u kojoj mjeri posebno redigiranje toga izdanja zahvatilo i sintaksu.

${ }^{10}$ Franjo Fancev smatra da te promjene možemo razumjeti samo ako pretpostavimo da su hrvatski protestanti u međuvremenu nabavili izvor koji ranije nisu imali (FANCEV 1916.a: 158), a koji bi mogla biti tajanstvena Biblija kojoj su se toliko trudili ući u trag (FANCEV 1916.a: 154-156), no nije nužno moralo biti tako. Moguće je i da su hrvatski protestanti već i na samome početku raspolagali kojim hrvatskoglagoljskim izvorom, ali svjesno nisu htjeli slijediti njegov jezik sve dok nisu bili suočeni s kritikama hrvatskoga glagoljaškog svećenstva i njegovim protivljenjem odabranim književnojezičnim uzorima. Da eventualno nabavljanje novih knjiga koje ranije nisu imali nije moralo presudno utjecati na razlike među dvama izdanjima, ističe i Stjepan Damjanović (DAMJANOVIĆ 2014: 65-67). Alojz Jembrih donekle modificira Fancevljevu pretpostavku, smatrajući da je jezično arhaiziranje možda i posljedica novih predložaka koje su sa sobom donijeli i u tiskari ostavili Matija Popović i Ivan Maleševac (JEMBRIH 2007.b: 43).

${ }^{11}$ Prijepore vjerojatno nije izazivala samo književnojezična osnovica već i otvoreno suprotstavljanje hrvatskih protestanata jeziku tradiranih hrvatskih liturgijskih knjiga u predgovorima, gdje kritiziraju misale i brevijare. U to je vrijeme ćirilometodska tradicija još uvijek morala biti poprilično snažna, stoga je takav svjestan otklon među glagoljaškim svećenstvom morao biti dočekan s neodobravanjem. Usp. »Stipan Konzul počeo je s prevođenjem Trubarovih knjiga; s njima je išlo relativno lako, jer ih je prevodio vjerno i doslovno, i to na onaj jezik za koji je tada znao da je najrazumljiviji na širem području [...]. Sa Svetim pismom, s Novim 
Takvih jezičnih razlika među izdanjima koja su prethodila Novomu testamentu nije bilo, što ne iznenađuje s obzirom na činjenicu da su pojedina od njih bila prvi hrvatski prijevod uopće. Hrvatski protestanti nisu uvijek imali domaći predložak na koji su se mogli osloniti, a kada su ga i imali, nisu se uvijek mogli ili htjeli njime služiti u jednakoj mjeri (usp. DAMJANOVIĆ 2017). U drugoj polovici 19. stoljeća Pavel Josef Šafař́k piše da glagoljičko i ćiriličko izdanje Novoga testamenta međusobno mnogo više odstupaju nego druge knjige hrvatskih protestanata, gdje se razlika svodi samo na pismo (ŠAFAŘ́IK 1865: 299). Franjo Bučar i Franjo Fancev tvrde da se glagoljičko i ćiriličko izdanje Table za dicu i Artikula jezično gotovo uopće ne razlikuju, dok je jezik u Katekizmu »tek [...] nešto okretan prema staroslovenskome« (BUČAR; FANCEV 1938: 54, 61, 95; usp. i VIDIC 1898: 116, 125-129). Njihovu tvrdnju potvrđuju i recentna istraživanja ranih izdanja hrvatskih protestanata. Zanemarimo li sadržajnu razliku u strukturiranju dijela početnice koji slijedi nakon tablice za sricanje slogova (sroka), ${ }^{12}$ dva se izdanja Table za dicu gotovo potpuno podudaraju; malobrojne razlike svode se tek na izbor pokojega leksema i pojedina grafijska rješenja (DAMJANOVIĆ 2007: 78). ${ }^{13}$ Glagoljičko i ćiriličko izdanje Artikula razlikuju se najčešće na grafijskoj i leksičkoj razini, dok su razlike na fonološkoj i morfološkoj razini malobrojne. ${ }^{14}$

Da su glagoljičko i ćiriličko izdanje Novoga testamenta sadržajno sasvim jednaki, ali »narodniji jezik glagolskoga izdanja u ćirilskom je ponešto arhaiziran u smjeru crkvenog slovenskoga jezika«, ponavljaju Franjo Bučar i Franjo Fancev (BUČAR; FANCEV 1938: 80). Na temelju usporedbe glagolskih oblika u Evanđelju po Mateju tih dvaju izdanja sa starijim hrvatskoglagoljskim tekstovima (gdje kao reprezentativne uzima četiri tiskana hrvatskoglagoljska misala 15. i 16. stoljeća: Misal hruacki Šimuna Kožičića Benje, 1531.; Misal Pavla Modrušanina, 1528.; Senjski misal, 1494.; Prvotisak, 1483.) Tanja Kuštović zaključuje da je riječ o jednome prijevodu i istoj književnojezičnoj koncepciji, a razlike koje se mjestimično pojavljuju na razini

testamentom [...] problem se zaoštravao: zašto napuštati jezik na kome postoje brojne, čak štampane knjige, i koji je kultiviran, okretan, razumljiv širokom krugu ljudi, utemeljen na dubljoj povijesnoj i jezičnoj tradiciji?«(BRATULIĆ 1983: 47).

${ }^{12}$ Poglavlje Kako se imaju slova izgovariti [izgovareti] sadrži u glagoljičkome izdanju za svako slovo po tri primjera riječi koje počinju tim slovom (među njima prevladavaju vlastita biblijska imena), a u ćiriličkome umjesto toga dolazi tekst po uzoru na stare azbučne molitve. Usp. DAMJANOVIĆ 2007: 7-8, 29-30, 77.

${ }^{13}$ Detaljniju lingvostilističku raščlambu obaju izdanja Table za dicu ponudile su Ana Gospić i Gordana Čupković (GOSPIĆ; ČUPKOVIĆ 2010).

${ }^{14}$ Detaljnije o obama izdanjima Artikula v. u nedavno objavljenim radovima: CEKOVIĆ 2016; ETEROVIĆ 2016; KUŠTOVIĆ 2016; KUŠTOVIĆ 2017; ŽAGAR 2016. 
grafije, glasova i oblika smatra tek posljedicom uređivanja jezika povećanjem broja »crkvenih « oblika s obzirom na to da je ocijenjen previše »narodnim« (KUŠTOVIĆ 2014: 127). Nasuprot tomu Gordana Čupković zastupa stav da je riječ o dvjema različitim ${ }^{15}$ književnojezičnim koncepcijama, premda se u cjelini može govoriti o čakavskome književnom jeziku i u jednome i u drugome izdanju (ČUPKOVIĆ 2010.b: 29). Među rezultatima njezina istraživanja provedena na odabranome korpusu obaju izdanja prvoga dijela Novoga testamenta dva autoričina uvida valja izdvojiti kao osobito vrijedna i poticajna za buduća istraživanja. Prvo, raščlambom odabranih fonoloških i morfoloških značajki podcrtala je važnost povećana unosa štokavizama kao protostandardnih elemenata, bolje zastupljenih u glagoljičkome izdanju, koji najavljuju koncepciju protureformacijskih nastojanja oko izgradnje naddijalektnoga idioma (ČUPKOVIĆ 2010.b: 6-11). ${ }^{16}$ Drugo, raščlambom odabranih semantosintaktičkih i leksičkih inačica ukazala je na sklonost različitim predlošcima: u glagoljičkome na načelno prilijeganje uz Lekcionar Bernardina Splićanina, a u ćiriličkome uz hrvatskoglagoljsku tradiciju (ČUPKOVIĆ 2010.b: 11-28). Ne smije se međutim smetnuti s uma, kako upozorava i sama autorica, da je tekstovna slojevitost obaju izdanja ipak umnogome složenija od takva pojednostavljena prikaza.

Mateo Žagar uočava da ključni čimbenik jezičnoga razlikovanja Novoga testamenta nije pismo već - vrijeme, odnosno da između drugoga dijela glagoljičkoga izdanja i ćiriličkoga izdanja (obaju otisnutih 1563.) postoji znatno više sličnosti i podudarnosti u odnosu na prvi dio glagoljičkoga izdanja (otisnut 1562.), za koji je osobito karakterističan povećan udio štokavskih elemenata (ŽAGAR 2017). ${ }^{17}$ Zaključuje da takva brza promjena književnojezične koncepcije unutar dvaju dijelova istoga izdanja svjedoči o »razmjerno hitnoj

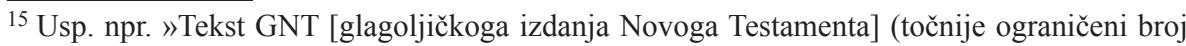
proučavanih ulomaka) zastupa koncepciju književnoga jezika bliska općemu razgovornom stilu i s tim u vezi očituje se tendencija za sužavanjem i specificiranjem značenja: jasnoća prevladava knjišku 'uzvišenost'. ĆNT [Ćiriličko izdanje Novoga testamenta] pokazuje suprotnu tendenciju: održavanjem visoka stila knjiškim leksemima širega značenjskog polja pokazuje se afirmativan stav i prema drugoj, crkvenoslavenskoj sastavnici glagoljaške tradicije. Izbor leksema naravno je određen prvenstveno izborom predloška, a tek sekundarno predodžbama o značenju« (ČUPKOVIĆ 2010.b: 19).

${ }^{16}$ Uključivanje štokavskih elemenata zabilježeno je i u glagoljičkome i latiničkome izdanju Katekizma, i to u potonjemu u većoj mjeri (JEMBRIH 1992; ČUPKOVIĆ 2010.a; DAMJANOVIĆ 2014: 158-159).

${ }^{17}$ Moguće je da će buduća istraživanja pokazati da pojedini »štokavizmi« zapravo dolaze iz predloška. Kako navodi Milan Rešetar, u Lekcionaru Bernardina Splićanina uočljive su dvije redakcije, koje primjerice odjeljuje - između ostaloga - status finalnoga slogovnog /1/ (nav. prema BRATULIĆ 1991: XII). 
promjeni opće jezične 'politike' «(ŽAGAR 2017). Pritom povećanje udjela štokavskih elemenata ne promatra kao posljedicu težnje za povećanjem razumljivosti, nego kao simbolično iskazivanje otvorenosti prema govornicima širega štokavskog prostora u kojih je uporaba njima bliskih inačica zasigurno stvarala dojam uključenosti i prihvaćenosti. ${ }^{18}$

\section{CILJ I KORPUS ISTRAŽIVANJA}

Usporedba glagoljičkoga i ćiriličkoga izdanja Novoga testamenta, načinjena u okviru projekta Jezik izdanja hrvatske protestantske tiskare u kontekstu književnojezičnih smjernica XVI. stoljeća ${ }^{19}$ pokazala je da se većina razlika odnosi na grafematičku i leksičku razinu. ${ }^{20}$ Budući da ih je teško zamijetiti

${ }^{18}$ Usp. »Popović i Maleševac došli su u Urach 20. rujna 1561., a posljednju su plaću dobili 10. veljače 1562. Kad bi se htjelo doznati koliki je bio njihov jezični utjecaj kod korektorskih zahvata, trebalo bi usporediti ćiriličko izdanje NT s glagoljičkim izdanjem NT, kao i tekst Ednih kratkih razumnih naukov (1562.), kod kojih su sudjelovali« (JEMBRIH 2007.b: 43). Iako Jembrih ne precizira smatra li rezultatom njihovih korektorskih zahvata inoviranje ili arhaiziranje dobivenoga prijevoda, ne može se isključiti mogućnost da veću zastupljenost štokavskih elemenata u jeziku Novoga testamenta valja pripisati (i) utjecaju dvojice bosanskih/uskočkih duhovnika. S obzirom na deficitarnost istraživanja hrvatske povijesne sintakse, osobito onih koja bi usporedbeno proučavala razlike između triju hrvatskih sustava (čakavskoga, kajkavskoga i štokavskoga), upitno je koliko se spoznaja relevantnih za utvrđivanje odnosa prema štokavštini može iščitati na temelju usporedbe dvaju izdanja Novoga testamenta na sintaktičkome planu.

${ }^{19}$ Projekt Jezik izdanja hrvatske protestantske tiskare u kontekstu književnojezičnih smjernica $X V I$. stoljeća, u okviru kojega je nastao i ovaj rad, financira Hrvatska zaklada za znanost (IP-2014-09-6415). Njegov je voditelj Mateo Žagar, a suradnici Blanka Ceković, Stjepan Damjanović, Ivana Eterović i Tanja Kuštović. Usporedba glagoljičkoga i ćiriličkoga izdanja Novoga testamenta uz predočavanje relevantnih jezičnih razlika te strukturirana pregleda i raščlambe tako dobivena korpusa bila je osnovnim ciljem u drugoj godini provedbe projekta. Mateo Žagar kritički je obradio prvu četvrtinu (prvi dio prvoga dijela Novoga testamenta), Tanja Kuštović drugu četvrtinu (drugi dio prvoga dijela Novoga testamenta), Ivana Eterović treću četvrtinu (prvi dio drugoga dijela Novoga testamenta), a Blanka Ceković četvrtu četvrtinu (drugi dio drugoga dijela Novoga testamenta).

${ }^{20}$ Ovdje ne izdvajam posebno tekstološku razinu, iako ju smatram temeljnom pri tumačenju razlika između dvaju izdanja Novoga testamenta i osnovnom smjernicom budućih istraživanja. Unatoč tomu što je još krajem 19. stoljeća prepoznata tekstološka ovisnost hrvatskoga protestantskog prijevoda o starijim čakavskim lekcionarima (v. u FANCEV 1916.a: 157-158; BRATULIĆ 1991: XVII; JEMBRIH 2007.b: 27-28, 60), začudan je izostanak interesa za usmjerenim sravnjivanjem Novoga testamenta s Bernardinovim lekcionarom. Posebno bi zahvalna bila usporedba s njegovim drugim izdanjem, kako se zaključuje na temelju riječi Primoža Trubara u predgovoru slovenskomu prijevodu Novoga zavjeta (JEMBRIH 2007.b: 27-28), na što je kao vrlo obećavajući put ukazala višeslojna usporedba Evanđelja po Mateju s njegovim potencijalnim izvorima. Naime Ivan Polovič utvrdio je da su dijelovi Evanđelja po Mateju koji su sadržani u lekcionarima preuzeti gotovo nepromijenjeni, a oni kojih u lek- 
i pronaći osim ciljanim istraživanjem, zbog čega su dosad i ostajale izvan dosljednijega dovida, cilj je ovoga rada (a) ispitati postojanje i čestotnost sintaktičkih razlika među dvama spomenutim izdanjima; (b) provjeriti potvrđuje li se i na sintaktičkoj razini različitost prvoga dijela glagoljičkoga s jedne i drugoga dijela glagoljičkoga i ćiriličkoga izdanja s druge strane. Istraživanje je pokazalo da su sintaktičke razlike većinom istoga tipa, premda svojim opsegom nisu ni približno toliko brojne kao razlike na drugim jezičnim razinama. ${ }^{21}$ Budući da ih je moguće grupirati u nekoliko skupina, u skladu s time bit će i prikazane u nastavku.

Sama odluka o tome što bi sve trebalo odrediti sintaktičkom razlikom veoma je podložna interpretaciji i raspravi. Naime manja podudarnost prvoga, odnosno veća sličnost drugoga glagoljičkog dijela s njima odgovarajućim ćiriličkim osobit je metodološki problem. Problematika različitih predložaka kojima su se hrvatski protestanti, kako se pretpostavlja, služili prilikom pre-

cionarima nema prevedeni prema Vulgati i slovenskomu predlošku. Slovenski utjecaj vidljiv je ponajprije u rubnim »sumama« (i pogreškama u njima, zbog čega autor zaključuje da su sume dodane u brzini nakon završetka prijevoda) (POLOVIČ 1908). Nove korake na tome putu napravila je u svojim jezikoslovnim istraživanjima Gordana Čupković, omjeravajući jezik odabranih odlomaka iz obaju izdanja prvoga dijela Novoga testamenta o Lekcionar Bernardina Splićanina i hrvatskoglagoljski Prvotisak iz 1483. godine (ČUPKOVIĆ 2010.b), odnosno pokušavajući identificirati inojezične utjecaje u onim odlomcima koje Bernardinov lekcionar ne sadrži (ČUPKOVIĆ 2013). Ipak, u nedostatku suvremeno priređena kritičkoga izdanja toga lekcionara služila se njegovim prvim izdanjem. Buduća bi istraživanja mogla detaljnije pokazati da protestanti pri služenju Bernardinovim lekcionarom nisu doslovno preuzimali tekst, nego su ga u određenoj mjeri i redigirali, pri čemu je možda koji hrvatskostaroslavenski predložak imao važnu ulogu (usp. POLOVIČ 1908: 62-67). Sličan proces možemo pratiti u Lajpciškome lekcionaru, ćiriličkome rukopisu čiji se nastanak prema najnovijim spoznajama na temelju analize vodenih znakova smješta u šesto ili sedmo desetljeće 16. stoljeća (BARBARIĆ 2012), a kojemu je predloškom bilo također drugo izdanje Bernardinova lekcionara: ondje gdje su u predlošku latinski dijelovi teksta, prepisivač Lajpciškoga lekcionara dopunio je prazna mjesta dijelovima preuzetim iz Prvotiska, ali ih je i podvrgnuo svojevrsnoj jezičnoj redakciji (više o tome v. u BARBARIĆ 2011, posebno na str. 15-17). Pokrenuta suvremena tekstološka istraživanja najstarijih hrvatskih lekcionara 15. i 16. stoljeća (BARBARIĆ 2015.a, 2017) bude nadu u mogućnost skora rasvjetljavanja te iznimno složene i zanimljive problematike.

${ }^{21}$ Osnovni je predmet hrvatskim protestantima suvremenih rasprava o jeziku bio dakle usmjeren na pitanje je li prijevod točan i dobar, a jezik razumljiv. Drugim riječima, kako je već ranije pokazano iz predgovora različitim izdanjima, u fokusu razmatranja bila je pravopisna i leksička ispravnost tekstova. Izjave koje se nisu doticale samo tih dviju razina veoma su rijetke i posve iznimno nalazimo osvrt na njihovu sintaksu. Primjerice fratar Ivan ocjenjuje prijevod vrlo lošim ne samo zbog brojnih pravopisnih pogrešaka već i zbog nepoštivanja hrvatskih fraza i konstrukcija (FANCEV 1916.a: 151; JEMBRIH 2007.b: 63). »Svjedoci i recenzenti« Fabijanić i Živić priznaju postojanje pravopisnih i tiskarskih pogrešaka, no naglašavaju da u rečenicama ne nalaze ništa pogrešno (FANCEV 1916.a: 152). 
vođenja detaljnije je izložena i protumačena u prethodnim bilješkama. Tomu ovdje dodajmo još Polovičevu pretpostavku (koja, nažalost, nije detaljnije razrađena) da je u drugome dijelu Novoga testamenta glavni izvor Vulgata (POLOVIČ 1908: 71). Posve je razumljivo da će se utjecaj različitih predložaka očitovati najviše na razini sintakse, frazeologije i leksika. Sintaktičkom razlikom stoga ne smatram svaku razliku na razini sintakse jer su mnoge od njih uvjetovane različitim leksičkim odabirom uslijed različita predloška. ${ }^{22}$ Umjesto toga sintaktičkim razlikama smatram samo one koje uključuju međusobno konkurentna i posve zamjenjiva sintaktička sredstva u izrazom što podudarnijem kontekstu, nastojeći postaviti što čvršću granicu između razlika uvjetovanih predloškom i onih neuvjetovanih njime, premda ona nužno ostaje vrlo tankom i elastičnom. ${ }^{23}$

Istraživanje je provedeno na korpusu neznatno manjem od polovice cjelokupnoga: potkorpus prvoga dijela Novoga testamenta uključuje stranice od početka do 30v i $98 \mathrm{v}-148 \mathrm{r}$, a potkorpus njegova drugoga dijela stranice od početka do 106r. Primjere iz glagoljičkoga dijela navodim prema nedavno objavljenim latiničkim prijepisima NT1 i NT2, ${ }^{24}$ a iz ćiriličkoga prema pretisku NTĆ i transliteracijskim načelima dogovorenima na projektu Jezik izdanja hrvatske protestantske tiskare u kontekstu književnojezičnih smjernica XVI. stoljeća (gdje je uvedeno razlikovanje dvaju znakova za nekadašnji poluglas: ' na mjestu title, b na mjestu jera). ${ }^{25}$ Kada je riječ o biblijskome primjeru, donosi se oznaka knjige, glave i retka. Kada nije riječ o biblijskome primjeru, donosi se oznaka dijela Novoga testamenta i stranice iz objavljenoga latiničkoga prijepisa gdje se primjer nalazi (npr. NT1: 310). ${ }^{26}$

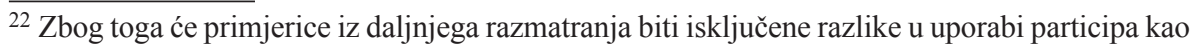
u primjeru I vlizući u hižu naidoše Ditića Z mariju materju negovu] I v'šadbšsi V domb naidoše dite z Mariju Materiju njegovu (Mt 2,11) ili pak u prijedložno-padežnim izrazima kao u primjeru ako dva izmei vami skladna budu] ako dva izbmeju vasb skladna budêta (Mt 18,19).

${ }^{23}$ Naravno, apsolutna dosljednost nije bila moguća, pa se pojedine razlike donose unatoč tomu što bi se i za njih vjerojatno moglo pokazati da su ovisne o predlošku, kao što su razlike u izricanju posvojnosti za treće lice u prvome dijelu glagoljičkoga izdanja ili pak uporaba genitiva s prijedlogom od u glagoljičkome ili bez njega u ćiriličkome izdanju. Budući da zadovoljavaju kriterij potpune međusobne zamjenjivosti, ovdje se ipak navode radi iscrpnijega sintaktičkog opisa.

${ }^{24}$ Budući da nije riječ o razlici koja bi bila važna za temu ovoga rada, zanemarujem razliku između dvaju načina bilježenja jera u glagoljičkome izdanju, rabeći isti tip apostrofa (') i na mjestu štapića i na mjestu apostrofa.

${ }^{25}$ Od dogovorenih načela odstupam u ovome radu jedino u bilježenju grafema šta u ćiriličkome izdanju, koji prenosim kao $c$ umjesto dogovorenoga $\hat{c}$.

${ }^{26}$ Prvi dio glagoljičkoga izdanja sadrži njemački izvornik i hrvatski prijevod predgovora Primoža Trubara, predgovor Stipana Konzula i Antuna Dalmatina te četiri evanđelja i Djela 


\section{SINTAKTIČKE RAZLIKE}

\subsection{Odabir konkurentnoga sintaktičkog sredstva}

\subsubsection{Izricanje posvojnosti}

U prvome dijelu Novoga testamenta posvojnost se izriče različito, osobito ona za treće lice. U Evanđelju po Mateju glagoljičko se izdanje od ćiriličkoga razlikuje time što se u prvome posvojnost za treće lice pretežno izriče posvojnom zamjenicom, a u drugome nesročnom imeničkom sintagmom koju čine imenica i genitivni oblik odgovarajuće lične zamjenice za treće lice: od ploda njihova] odb ploda njihb (Mt 7,16); od stran njihovih] odb stranb njihb (Mt 8,34); u njihovu Sinagogu] v' njihь Sinagogu (Mt 12,9); mišlenija njihova] mišljenija njih (Mt 12,25); V sinagogi nihovoi] v njihb Sinagogi (Mt 13,54); sr'ce nihovo] s'rdbce nihb (Mt 15,8); krivice nihove] krivice nihb (Mt 18,35); oči nihove] Oči njihb (Mt 20,34); oči nihovi] Oči njihs (Mt 20,34). U Evanđelju po Ivanu potvrđuje se potpuno suprotna praksa, gdje zamjena posvojnom zamjenicom sada preteže u ćiriličkome izdanju: mati njega] Mati njegova (Iv 2,12); Otac njega] Otacb njegovb (Iv 5,18); u svitlosti njega] va svitlosti njegovi (Iv 5,35); krvi njega] k'rvi njegove (Iv 6,53); zapovêd njega] zapovêd njegova (Iv 12,50). ${ }^{27} \mathrm{U}$ Evanđelju po Luki potvrđuju se obje prakse: od ust njega] izb ustb njegovihb (Lk 11,54); š njihovimi posvetilišći 1 š njihb Posvetilišći (Lk 13,1); dobra njega] blago njegovo (Lk 16,2); zled njihovu] zlobu njihb (Lk 20,23).

Genitivnim oblikom upitno-odnosne zamjenice ki posvojnost se u ćiriličkome izdanju izriče i u primjeru čigov današni dan] koga današni dan' (NT1: 310), dok u glagoljičkome dolazi nominativni oblik upitno-odnosne zamjenice čigov.

Glagoljičko i ćiriličko izdanje posve se iznimno razlikuju u uporabi povratno-posvojne zamjenice. U primjeru iz glagoljičkoga izdanja Ivan tada imiaše svitu od ${ }^{28}$ dlak Kamelskih, i koženi pas okol ledav njegovih (Mt 3,4) posvojna zamjenica zamijenjena je povratno-posvojnom u ćiriličkome (svoihb). U primjeru da ga nikako ne potapću z nogami svoimi (Mt 7,6) povratno-posvojna zamjenica zamijenjena je genitivom odgovarajuće lične zamjenice u posvojnome značenju (̌̌ nji $\langle h\rangle_{b}$ nogami).

apostolska, a drugi dio apostolske poslanice i Otkrivenje Ivanovo, »sve uz pripadajuće predgovore i komentare, prema uzusima protestantske Biblije XVI. stoljeća« (NT2: 8).

${ }^{27}$ Franjo Fancev ustvrđuje da se u jeziku hrvatskih protestanata umjesto posvojnih zamjenica njegov, njezin i njihov često rabe i stariji oblici genitiva njega, nje(je) i njih (FANCEV 1916. b: 95). Većina je primjera koje navodi iz drugih djela hrvatskih protestanata.

${ }^{28}$ U latiničkome prijepisu NT1 ovdje je pogrešno ot. 
Različit sintaktički izbor za izricanje posvojnosti vidljiv je i u primjerima drugoga tipa. Sintaktička razlika $u$ Kani ot Galilee] V kani galileiskoi (Iv $2,1)$ podrazumijeva uporabu posvojnoga genitiva s prijedlogom od u glagoljičkome izdanju naspram odnosnoga pridjeva u ćiriličkome. Da odnosnim pridjevom ne mora biti zamijenjen samo genitiv s prijedlogom od već može i besprijedložni genitiv, potvrđuje primjer zrno pšenice] Zr'no Pšenično (Iv $12,24)$.

U drugome dijelu Novoga testamenta takvih razlika gotovo i nema. Jedina razlika u odabranome sintaktičkom sredstvu za izricanje posvojnosti potvrđena je u primjeru va Anjelsku svitlost'] va Angela svitlosti (2 Kor 11,14), gdje je u ćiriličkome izdanju prednost dana besprijedložnom posvojnom genitivu.

\subsubsection{Sintaksa padeža}

U prvome dijelu Novoga testamenta česta sintaktička razlika između dvaju izdanja posljedica je veće sklonosti prema uporabi genitiva $\mathrm{s}$ prijedlogom od u glagoljičkome izdanju, koji se u ćiriličkome zamjenjuje besprijedložnim genitivom: KNIGA OD ROISTva] KNIGE ROISTVA (Mt 1,1); ribara od ljudi] ribara ljudi (Mt 4,19); Evangelie od kraljestva] Evangelie Kraljevstva (Mt 4,23); Ovcam, od hiže Izdrajelske] Ovbcamb, Hiže Izbdrajelsbke (Mt 10,6); zlamenja od vrimen] zlamenja vrimenb (Mt 16,3); Dom od molitve] Domb molitve (Mt 21,13); Ključ od znanija] Ključb znanja (Lk 11,52); Otac od obiteli] Otacb obiteli (Lk 13,25); h koncu od gorê Maslinske] h koncu gorê Maslinske (Lk 19,37); Dom od molitve] Domb molitve (Lk 19,46); Jamu od razboinikov] Jamu razboinikovb (Lk 19,46); Starešine od puka] Starešine p'lka (Lk 19,47); Gospodin od Vinograda] Gospodinb Vinograda (Lk 20,13); otcu ot obiteli] Otcu obiteli (Lk 22,11); kaplje ot krvi] kaplje k'rvi (Lk 22,44); Niednoga uzroka od smrti] Nijednoga uzroka Sm'rti (Lk 23,22); trgovce ot pinezi ${ }^{29}$ ] prominjavce Pinezb (Iv 2,14); Hižu od Trga] Hišu Trbgovine (Iv 2,16); uskrsnut'je ot života] vsk'rsnutbje života (Iv 5,29); uskrsnut'je od osuenija] vsk'rsnutbje osujenbja (Iv 5,29); po videniju od obraza] po videnbju obraza (Iv 7,24); pogibêl ot narod] razidenije Narodb (Iv 7,35); ponovljenje ot Templa] ponovljenbje Templa (Iv 10,22). Kako pokazuju primjeri, ta zamjena ne ovisi o značenju genitiva, no ipak se može zamijetiti da prevladava posvojno. Mogućnost zamjene subjektnoga genitiva s prijedlogom od i kojim drugim sintaktičkim sredstvom iskorištena je u primjerima skripanje od zub] škripanbje zubomb (Mt 8,12); škripanje od Zub] škripanbje Zubi (Lk 13,28), gdje je »nedopuštena« uporaba prijedloga

${ }^{29}$ U latiničkome prijepisu NT1 ovdje je pogrešno pinez. 
$o d$ u prvome slučaju razriješena besprijedložnim instrumentalom, a u drugome besprijedložnim genitivom. ${ }^{30}$

U niječnoj konstrukciji akuzativ iz glagoljičkoga izdanja zamijenjen je genitivom u ćiriličkome, ${ }^{31}$ češće u prvome dijelu Novoga testamenta, u primjerima Dobro drivo, ne more zal plod ćiniti] dobro drivo, ne more zbla ploda činiti (Mt 7,18); ne umivaju ruke svoje] ne umivaju rukb svoihb (Mt 15,2); ruke ne umije] rukb ne biše umilb (Lk 11,38); zašto nakladate ljudem brêmena, koja nositi ne mogu] začto nakladate ljudemb brêmena, kihb nositi ne mogu (Lk 11,46); ne bi dal podkopati Hižu svoju] Ne bi dalo podkopati Hiže svoje (Lk 12,39); ne navidi Otca svoga, i Mater] ne v'znenavidi Otca svoga, i Matere (Lk 14,26); koi godi ne nosi križ svoi] ki godi ne nosi križa zvoga (!) (Lk 14,27); zašto nêsi dal pinezi moe] začto nisi dalb Pinezb moih (Lk 19,23); Ovi bo niedno zlo nê stvoril] Ovi bo nijednoga zla ni stvorilb (Lk 23,41); ne naidoše Têlo Gospodina ISUSA] ne naidoše Têla Gospodina ISUSA (Lk 24,3); svidočastvo ne prijimlju] svidočastva ne prijimlju (Iv 5,34); slavu (...) ne išćete] slavê (...) ne išćete (Iv 5,44); Ne li vam Moisei dal zakon] Ni li vamb Moisei dalb zakona (Iv 7,19); govorenje moe ne spoznate] govorenbja moga ne spoznate (Iv 8,43); dok je u drugome dijelu pronađen samo jedan takav primjer u pregledanome korpusu: živinu v'Crikvi ne kolêmo] živinê Vb crikvi ne koljemo (NT2: 29). ${ }^{32}$

Vremenski genitiv iz glagoljičkoga izdanja zamijenjen je vremenskim akuzativom u ćiriličkome u primjeru pusti ju ošće i ovoga godišća] pusti ju ošće i ovo Lêto $(\operatorname{Lk} 13,8) .{ }^{33}$

Sklonost prijedložno-padežnim izrazima u glagoljičkome izdanju vidljiva je i iz primjera Pogledaite na lilie] Pogledaite lilije (Mt 6,28).

\footnotetext{
${ }^{30}$ Ovaj je tip razlike između glagoljičkoga i ćiriličkoga izdanja Novoga testamenta zamijetila i Gordana Čupković, ali ga je potvrdila u drugome korpusu (ČUPKOVIĆ 2010.b: 19-20). Uočio ga je još i Franjo Fancev, koji uporabu besprijedložnoga genitiva u ćiriličkome izdanju pripisuje »starijoj redakciji biblijskog prijevoda « (FANCEV 1916.a: 154). Luka Zima navodi da je uporaba genitiva s prijedlogom od česta u starih čakavskih i dubrovačkih pisaca (ZIMA 1887: 213-214).

${ }^{31}$ Isto vrijedi i za dijelni genitiv (ČUPKOVIĆ 2010.b: 19).

32 Pomnije čuvanje genitiva negacije prepoznatljiva je značajka hrvatskoga staroslavenskog jezika, iako se vrlo rano na njegovu mjestu sve više počinje pojavljivati akuzativ (HCJ 2014: 322-324). O čimbenicima o kojima ovisi zamjena genitiva izravnoga objekta akuzativom v. više u VINCE 2008. Rezultati toga istraživanja mogu biti posebno zanimljivi jer je autorica primjere za starohrvatski jezik ekscerpirala iz Lekcionara Bernardina Splićanina i Ranjinina lekcionara.

${ }^{33}$ Luka Zima pronašao je samo nekoliko primjera vremenskoga akuzativa u starih čakavskih pisaca (ZIMA 1887: 228). Na temelju izostanka primjera za vremenski genitiv, odnosno brojnih primjera za vremenski akuzativ u HCJ (2014: 320-327, 333-334), može se zaključiti da je u hrvatskome staroslavenskom jeziku običnija bila uporaba drugoga od njih.
} 
U ćiriličkome se izdanju teži većoj dosljednosti u uporabi prvotnoga prijedloga $k \mathrm{~s}$ dativom pri pozivanju na apostolske poslanice $\mathrm{u}$ tekstu, no posve je uobičajen i njegov izostanak u tome kontekstu u obama izdanjima: Rimla(nom)] $k$ Rim(lanom) (NT1: 45); filip(iem)] K filip(iem) (NT2: 20); Rim(lanom)] Krim(lanom) (NT2: 32). Posve su iznimni takvi primjeri u biblijskome tekstu: reče filipu] reče K filipu (Iv 6,5). Samo u jednome primjeru prijedlog $k$ iz glagoljičkoga izdanja izostaje u ćiriličkome: I niki ot Farizei ${ }^{34}$ (...) rekoše k njemu] I niki otb farisei (...) rekoše njemu (Lk 19,39). Prijedlog $k$ rabi se uvijek u glavnim naslovima i zaglavljima.

U glagoljičkome izdanju nekoliko je primjera besprijedložnoga instrumentala koji se u ćiriličkome zamjenjuje instrumentalom s prijedlogom $s(a)$ : pravadne verne sobom privesti hoće] pravadne verne s'sobomb privesti hoće (NT1: 62); Imei dobrovolnost suprotivnikom tvoim brzo] Imei dobrovolnostb zb suprotivnikom tvoimb b'rzo (Mt 5,25); govoraše bo sama soboju] govoraše bo sama sb soboju (Mt 9,21); vaze sobom sedam inih duhov] vaze sa sobomb sedamb inih duhovb (Mt 12,45); vodeći sobom hrome] vodeći sa sobomb hrome (Mt 15,30); tada počneš stidom zadnje mêsto držati] tada počnešb sa stidomb zadnje mêsto d'ržati (Lk 14,9); Skupihu se Poglavice popovske, i pisci Starišinami] Skupiše se Poglavice Popovske, i Pisci sa Starišinami (Lk 20,1). ${ }^{35} \mathrm{U}$ svim je navedenim primjerima riječ o instrumentalu društva, osim predzadnjega primjera, gdje se radi o instrumentalu načina. U tim je prijedložno-padežnim izrazima početno slovo imenske riječi koja dolazi uz prijedlog upravo $s$, što može upućivati na to da ga valja pretpostaviti i u glagoljičkome izdanju, iako je nezabilježeno u pismu (kao rezultat gubljenja uslijed alternacije). ${ }^{36} \mathrm{U}$ svakom slučaju, u ćiriličkome izdanju odabrano je jednoznačno - ujedno i jasnije - rješenje. U trima primjerima u ćiriličkome izdanju instrumental s prijedlogom $s(a)$ u značenju sredstva zamijenjen je besprijedložnim instrumentalom: $s$ čim hoćemo se oditi] čim se hoćemo oditi (Mt 6,31); nimaš š čim bi začrpal] nimašb čim bi zač 'rpalb (Iv 4,11); bêše zavit z obrusom] biše zavitb obrusomb (Iv 11,44).

\subsubsection{Dvojina / množina}

Velik broj razlika odnosi se na pomnije zadržavanje sročne dvojine u ćiriličkome izdanju, zbog čega je množinski oblik finitnoga glagola iz glagoljič-

\footnotetext{
${ }^{34}$ U latiničkome prijepisu NT1 ovdje je pogrešno Farisei.

${ }^{35}$ Luka Zima pronalazi slične primjere u starih čakavskih i dubrovačkih pisaca, dok u štokavštini prijedlog načelno ne izostaje (ZIMA 1887: 244-246).

${ }^{36}$ Usporedbe radi zanimljivo je ovdje napomenuti da se u primjerima koje Irena Miloš navodi za besprijedložnu uporabu instrumentala u čakavskome ekavskom dijalektu u šest od osam slučajeva radi o imenskoj riječi na čijem su početku $s$ ili $̌$, dok istovremeno ni u jednome primjeru prijedložne uporabe nema takve riječi (MILOŠ 2016: 94-95).
} 
koga izdanja na više mjesta zamijenjen dvojinskim: Kada be zaručena Mati Isusova Maria Osipu, prvo nego se znidoše] Kada bê zaručena Mati ISUSOVA Maria Osipu, p'rvo nego se snidosta (Mt 1,18); učiniti ću vas da budete ribara od ljudi] učiniti ću vasb da budeta ribara ljudi (Mt 4,19); Jere ako Slipac, Slipca vodi, oba v jamu padut] Jere ako Slipacb, Slipca vodi, oba vb jamu padeta (Mt 15,14); ako dva izmei vami skladna budu] ako dva izbmeju vasb skladna budêta (Mt 18,19); ondê nam pripravite] ondê namb pripravita (Lk 22,12); I ona dva gredući, naidosta kako ĵim biše rekal ISUS] I ona dva gredući, naidosta kako njima biše rekalb ISUS (Lk 22,13); za nje prijîmlemo] za nje prijemljeva (Lk 23,41); oni pravlahu, koja bêhu učinjena na putu, $i$ kako ga poznaše $v$ razlomljeniju kruha] ona pravlahota, ka bêhu učinjena na putu, i kako ga poznasta v razlomljenьju kruha (Lk 24,35). Većina primjera zabilježena je u prvome dijelu Novoga testamenta. No da to nije nužno povezano s pitanjem predloška, potvrđuje i jedan takav primjer iz drugoga dijela: ako budete jila] ako budeta jala (NT2: 40). Ipak, u pregledanome je korpusu potvrđen i jedan primjer u kojemu se dvojinski oblik rekosta iz glagoljičkoga izdanja u ćiriličkome zamjenjuje množinskim rekoše u priči o dva jerihonska slijepca (Mt 20,20-34).

\subsubsection{Infinitiv / da-konstrukcija}

U primjeru Grih' ovi jest' Gospodina Boga tako razs'rdil' i človika tako hudobna, kriva i dužna učinil', da jest' bilo sila Božjoi pravdê i istini nêga (...) potle večnomu proklêtstvu izdati i podložiti] Ovi Grihb jestb Gospodina Boga tako razs 'rdil' i človika tako hudobna, kriva i d'lžna učinilb, da jest' bilo sila Božbioi pravdi i istini da ga (...) potle večnomu proklêvstvu (!) izda i podbloži (NT2: 38) uz sintagmu modalnoga značenja (biti sila 'morati') umjesto dopune u infinitivu u glagoljičkome izdanju dolazi konstrukcija da + prezent $\mathrm{u}$ ćiriličkome.

\subsubsection{Participi $i^{37}$}

U jednome je slučaju zabilježena razlika u uporabi apsolutnih konstrukcija između glagoljičkoga i ćiriličkoga izdanja ${ }^{38}$ u prvome primjeru dolazi ap-

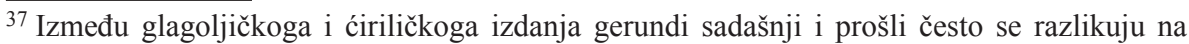
razini oblika s obzirom na nastavak, no ovdje takve primjere ne komentiram jer zapravo pripadaju morfologiji. Terminom gerund označujem nesklonjiv particip u funkciji sekundarnoga predikata, kako to čini Ivana Vrtič (VRTIČ 2010).

${ }^{38}$ Premda je metodološka ispravnost navođenja ovakvih primjera u okviru sintaktičkih razlika upitna s obzirom na njezinu vjerojatnu uvjetovanost različitim predlošcima, ipak navodim i ovu razliku zbog njezine zanimljivosti i jedinstvenosti u pregledanome korpusu.
} 
solutni nominativ, a u drugome apsolutni dativ Poslušajući oni ova, priloživši reče priliku] Ova njims poslušajućimb, priloživši reče priliku Lk 19,11. ${ }^{39}$

U bilješci Paval skrbi za kolosijane: opomina ih k stanovitstvu da se ne dadu lastivim' slatkim' besedam' NT2: 250 (bilj.) drugi je prezentski oblik iz glagoljičkoga izdanja zamijenjen gerundom opominajući u ćiriličkome izdanju, čime je prednost dana tradicionalnomu sintaktičkom sredstvu za izricanje istovremenosti predikatske radnje.

\subsubsection{Sročnost}

Pojedine sintaktičke razlike u pregledanome korpusu posljedica su kolebanja u sročnosti. U primjeru s višečlanim subjektom ovo naše tumačenje, $i$ ova naša slova ne bude ugodno] ovo naše tumačenbje, i ova naša Slova ne budu ugodna (NT1: 51) predikat se slaže s daljim subjektom u glagoljičkome izdanju, a u ćiriličkome s bližim. Različito je rješenje odabrano i u primjeru da meju sobu jedan'od' drugoga straćeni ne budete] da meju sobu jedanb odb drugoga straćenb ne bude (Gal 5,15).

\subsection{Red riječi}

U obama dijelovima Novoga testamenta velik broj sintaktičkih razlika između glagoljičkoga i ćiriličkoga izdanja odnosi se na različit red riječi. ${ }^{40} \mathrm{U}$ drugome dijelu to je ujedno osnovna i najbrojnija skupina potvrđenih razlika.

\subsubsection{Zanaglasnice}

Najbrojniji su primjeri u kojima se u ćiriličkome izdanju mijenja redoslijed zanaglasnica ${ }^{41} \mathrm{u}$ odnosu na onaj koji dolazi u glagoljičkome, $i$ to posebice kada je riječ o nenaglašenim oblicima povratne zamjenice sebe. ${ }^{42}$

\footnotetext{
${ }^{39}$ Druge primjere apsolutnoga nominativa iz hrvatskoga protestantskog prijevoda Novoga zavjeta v. u VRTIČ 2010.

${ }^{40}$ Moguće tumačenje takvih razlika v. u ČUPKOVIĆ 2010.b: 23-25, gdje se razlika u redu riječi tumači u prvome redu različitim shvaćanjem odsječaka koje valja posebno istaknuti ili naglasiti.

${ }^{41}$ U vezi s enklitičkim oblicima u jeziku hrvatskih protestanata Franjo Fancev navodi da je red riječi »isti kao i u današnjem jeziku«, a da se stariji, u kojemu zamjenički enklitički oblici prethode glagolskim, susreće tek ponegdje (FANCEV 1916.b: 95). Među primjerima koje navodi nijedan nije iz Novoga testamenta.

${ }^{42}$ Luka Zima određuje redoslijed zanaglasnica jednom od temeljnih razlika između čakavštine, kajkavštine i štokavštine; samo u štokavštini zamjenički oblici »slijede pravilno« iza glagol-
} 
Osnovna tendencija koja se može zamijetiti jest pomicanje enklitičkih oblika povratne zamjenice bliže početku rečenice. ${ }^{43}$ To pomicanje zahvaća ponajprije primjere u kojima se nenaglašeni oblik povratne zamjenice našao na početku naglasne cjeline: ako sol se skvari] ako se solb skvari (Mt 5,13); I tomu koi s tobom se hoće pravdati] I tomu koi se s tobomb hoće pravdati (Mt 5,40); s čim hoćemo se oditi] čim se hoćemo oditi (Mt 6,31); počeše svitovati se suprotiva njemu] počeše se svitovati suprotiva njemu (Mt 12,14); is ploda spozna se drivo] isb ploda se spozna drivo (Mt 12,33); Zašto za drugo se brinete] Začto se za drugo brinete (Lk 12,26); da ni Salomun (...) se ne oblačaše kako jedna od njih] da se ni Salomunb (...) ne oblačaše kako jedna odb njihb (Lk 12,27); A ona on hip se stegnu] A ona se onb hipb stegnu (Lk 13,13); Kad paki Otac od obiteli se ustane] Kad se paki Otacb obiteli vbstane (Lk 13,25); A oni svi se počeše odnimati skupa] A oni se vsi počeše odnimati skupa (Lk 14,18); I ako sedam krat na dan se povrati k tebê] I ako se sedamb kratb na danb povrati k tebi (Lk 17,4); dan u ki Sin čovičaski se javi] danb v ki se Sinb človičaski javi (Lk 17,30); ki mnjahu da Kraljestvo Bož’je se ima brzo očitovati] ki mnjahu da se Kraljevstvo Božbje ima b'rzo očitovati (Lk 19,11); koi zaedno se bêhu skupili] ki se zajedno bêhu skupili (Lk 23,48); Zato jure imamo (...) hvaležni i spoznani se iskazati] Zato se jure imamo (...) hvaležni i spoznani iskazati (NT2: 35); mnogokrat'va svetom' Pismu (...) se razumi] mnogokrat se va svetomb Pismu (...) razumi (NT2: 43); Jere gnjiv' Božǰi se javla] Jere se gnjivb Božbi javla (Rim 1,18); Ali greh'se ne priluči] Ali se grehb ne priluči (Rim 5,13); da zlo se v'meni ud'rži] da se zlo v' meni ud'rži (Rim 7,21); kako ti krivi hinbeni Krst'jani se imaju proklinati] kako se ti krivi hinbeni Kbrstbjane imaju proklinati (NT2: 121); da v Crikvi (...) se imaju] da se v Crikvi (...) imaju (NT2: 124); kad'za riči, ke k tomu životu pristoe se pravdate] kadb se za riči, ke k tomu životu pristoje pravdate (1 Kor 6,4); Kad'vi tada kupno v'jedno mesto se snidete] Kada se vi tada kupno v'jedno mesto snidete (1 Kor 11,20); kako (...) se boje] kako se (...) boje (NT2: 205);

skih (ZIMA 1887: 64-70). Možda bi se u razlikama u redu riječi, koje će biti prikazane u nastavku, eventualno mogao tražiti utjecaj »uskočkih duhovnika«, no pritom ostaje neodgovorenim pitanjem zašto bi upravo tomu zadatku bilo dano tako važno mjesto pri korekturi povrh onoga temeljnog koji je i izazivao najviše rasprave, a to je svjesno udaljavanje od tradiranoga liturgijskog jezika. Dodajmo ovdje da su u hrvatskome staroslavenskom jeziku zamjeničke enklitike potvrđene i ispred i iza glagola (HCJ 2014: 317). Izmjene u redu riječi kakve nalazimo u Novom testamentu mogle bi biti određene težnjom za većom prilagodbom usmenoj dimenziji teksta.

43 Tendenciju pomicanja enklitika bliže početku rečenice kao tipičnu za hrvatska narječja izdvaja Stjepan Ivšić (IVŠIĆ 1967: 113 i dalje). O položaju enklitika u hrvatskome jeziku uopće, uz osvrt na specifičnosti svakoga pojedinoga hrvatskoga jezičnog sustava, v. više u IVŠIĆ 1967: 112-125. 
veli (...) uteći se] veli se (...) uteći (NT2: 206); Čudim se da (...) tako brzo se preseljujete] Čudim se da se (...) tako b'rzo preseljujete (Gal 1,6); Jere vas' Zakon' (...) se udrži] Jere se vas'Zakonb (...) udrži (Gal 5,14). ${ }^{44}$

Pomak nenaglašenoga oblika povratne zamjenice bliže početku rečenice zabilježen je međutim i u onih primjera u kojima nije bio na početku naglasne cjeline: a zjutra u peć se stavi] a zbjutra se v'pećb stavi (Mt 6,30); i zato kriposti u njem se čine] i zato se kriposti v njems čine (Mt 14,2); Zato mi K'rst'jani veće se ne obrezujemo] Zato se mi Kbrstbjane veće ne obrezujemo (NT2: 29); I ako prem' niki nikoliko se d'rže] I ako se premb niki nikoliko d'rže (NT2: 32); Ona nista za Boga marila, ni bojala se nêga kaštige] ona nista za Boga marila, ni se bojala njega kaštige (NT2: 39); Zato sam'sveti Paval' (...) očito se daje] Zato se samb sveti Pavalb (...) očito daje (NT2: 44); ki cića straha $i$ bez' ljubave počteno se drže] i ki se radi straha i prezb ljubave počteno drže (NT2: 58); Zato od' toga (...) nikomur se nima grustiti] Zato se odb toga (...) nikomurb nima grustiti (NT2: 197); ali š njimi (...) obdržati se] ali se š njimi (...) obd'rbžati (NT2: 202); da ja vsagda i va vsako vrime (...) spominam se na vas'] da se ja vsagda i va vsako vrime (...) spominamb na vasb (Rim 1,9-10); ti po prestuplên'ju zakona Bogom'se rugaš'] ti se po prestuplênbju Zakona Bogomb rugašb (Rim 2,23); nego stvori se Krêpak' va Veri] nego se stvori Krêpakb Va veri (Rim 4,20); Tako i vi se d'ržite] Tako se $i$ vi d'ržite (Rim 6,11 ); zato sprave radujem se s vami] zato se istinno radujemb s vami (Rim 16,19). Prednost je dakle dana alternativnomu rješenju.

Da nije riječ o posve dosljednoj tendenciji, pokazuju primjeri u kojima se enklitički oblik povratne zamjenice našao iza sintagme. Iako postoji mogućnost njegova daljnjega pomaka prema početku rečenice, pomak može i izostati: $i$ vi tih istih brêmen z jednim vašim prstom se ne dotaknete] $i$ vi tihb istihb brêmen se zb jednimb vašimb p'rstomb ne dotaknete (Lk 11,46); Od'vaše Vere po vsem' svitu se navišćuje] Odb vaše Vere se po vsemb svitu navišćuje (NT2: 24); Ta ista kada godi se razumi] Ta ista se kada godi razumi (NT2: 42); I od' te iste ne daite se] I odb te iste se ne daite (NT2: 56). ${ }^{45}$

Uređivanje redoslijeda nenaglasnica potvrđuje se i u primjerima suprotna pomaka, gdje se zanaglasnica pomiče s početka na kraj izgovorne cjeline: $i$ se narinuše na oni dom] $i$ narinuše se na oni domb (Mt 7,25); $i$ ga je odlučil' $i$

\footnotetext{
${ }^{44}$ Usporedbe radi zanimljivo je ovdje navesti da i Bartol Kašić u svojemu prijevodu Biblije pomiče zamjeničke zanaglasnice bliže početku rečenice u odnosu na njihov položaj u latinskome predlošku (VELA; VRTIČ 2013: 665-666).

45 Tendenciju za nerazbijanjem sintagme zanaglasnicom »u starini« hrvatskoga jezika prepoznaje Stjepan Ivšić (IVŠIĆ 1967: 116). Položaj zanaglasnice iza sintagme kao najčešći potvrđen je primjerice i u suvremenoj kajkavštini u starijih govornika (RAMADANOVIĆ; VIRČ 2013: 625).
} 
postavil'] i odlučilb ga je i postavilb (NT2: 21); ž nêga s(ve)tu muku i Krv'ju se rugaju] ž njega s'vetu muku i Krv'ju rugaju se (NT2: 204); ta isti ima pokoi $v$ konsiencii svojoi, se ufa od'boga stanovite pomoći] ta isti ima pokoi V konsiencii svoioi, ufa se odb Boga stanovite pomoći (NT2: 205).

Promjena mjesta bliže početku rečenice zahvaća i druge zanaglasnice (nenaglašene oblike ličnih zamjenica te prezenta i kondicionala pomoćnoga glagola biti), no u manjoj mjeri: Zašto Gospodin ga potrebue] Začto ga Gospodinb potrebuje (Lk 19,34); David tada Gospodinom ga zove] Davidb ga tada Gospodinomb zove (Lk 20,44); I evo ništare mu ni dostoina od smrti učinil] I evo mu ništare ni dostoina Sm 'rti učinilb (Lk 23,15); jere sami smo slišali] jere smo sami slišali (Iv 4,42); I zato su Judei ošće veće iskali ga ubiti] I zato su ga Judei ošće veće iskali ubiti (Iv 5,18); nitkore ne more oteti jih iz ruk Otca moga] niktore ih ne more oteti iz rukb Otca moga (Iv 10,29); i kako njih' meso ili plt', i njih' skvarena Natura bi hotêla] $i$ kako bi njih' meso ili pl'tb, i njihb skvarena Natura hotêla (NT2: 35); Jere ako radi grêha jednoga človika mnogo ih' jest' um 'rlo ${ }^{46}$ ] Ako ihb jestb radi Grêha jednoga Človika mnogo um'rlo (NT2: 43); ali zato nisu joi pravo verovali] ali bioi zato nisu pravo verovali (NT2: 59); Ne znajuć' da dobrota Bož'ja te k'pokorje vabi] Ne znajućb da te dobrota Božbja k' pokori vabi (Rim 2,4); ki za kako godi mal'ahne svitovne riči su se prêd' Poganskimi sudci pravdali] ki su se za kako godi maljahne svitovne riči prêdo Poganskimi sudci pravdali (NT2: 122); Stanovito slaviti ništar' mi se ne prudi] Stanovito slaviti mi se ništarb ne prudi (1 Kor 12,1); ki nigda proganaše nas'] ki nasb nigda proganjaše (Gal 1,23). Prilikom pomicanja nenaglašeni oblik može biti zamijenjen naglašenim: Moje saznan 'je v niednoi stvari me kriva ne čini] Moje saznanbje mene v niednoi stvari kriva ne čini $(1$ Kor 4,4). Isto tako naglašeni može biti zamijenjen nenaglašenim: reče tada njemu Bog] Reče mu tada Bogb (Lk 12,20).

Jedina razlika između glagoljičkoga i ćiriličkoga izdanja koja odstupa od izloženih načela u pregledanome korpusu jest ona u primjeru Ona se jesta (...) z Bogom 'narugala] Ona sta se (...) z Bogomb narugala (NT2: 40), gdje je izmjena možda stilski uvjetovana s obzirom na paralelizam u strukturi cijeloga odlomka iz kojega je primjer ekscerpiran (usp. Četrto: ona sta se preveliko brinula [...]. Peto: Ona sta ohola i nesramna bila [...]. Šesto: Ona se jesta [...] z Bogom' narugala. Sedmo: Ona jesta veće D'javlu nego Bogu verovala [...]. Osmo: Ona sta bila suprot'Bogu vele nehvalna [...]. Deveto: Ona jesta sama sebe [...] navela i porinula, i proč(aja) NT2: 40-41).

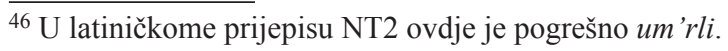




\subsubsection{Atribut}

Sročni atribut prelazi iz postpozicije $\mathrm{u}$ glagoljičkome izdanju u antepoziciju u ćiriličkome u primjerima vêra kr'stianska] K'rstjanska Vera (NT1: 45); u Hiže vikovične] va vikovične krovê (Lk 16,9); Grih' ovi] Ovi Grihb (NT2: 38); sa vsimi dari njegovimi] sa vsimi njegovimi dari (NT2: 43); tih'udi zvan skih'] tihb zvanbskihb udi (NT2: 54); delih' naših'] našihb delihb (NT2: 197). ${ }^{47}$ Prijelaz iz antepozicije iz glagoljičkoga izdanja u postpoziciju u ćiriličkome zabilježen je u primjerima tvoe Têlo] Têlo tvoje (Lk 11,34); svoje meso] p'ltb svoju (Iv 6,52); moe meso] p'ltb moju (Iv 6,54); moju krv] k'rvb moju (Iv 6,54); moe meso] P'ltb moju (Iv 6,56); moju krv'] Krvb moju (Iv 6,56); on Božj̧i Sin] on Sinb Božbi (Iv 11,27).

Prijelaz atributa širega značenjskog opsega na prvo mjesto u ćiriličkome izdanju zabilježen je u primjeru druga nêka] nika druga (NT2: 23). Takva promjena ne mora nužno zahvatiti sve sročne atribute u pojedinoj sintagmi: Grade sve Izdrajelske] vse Grade Izdrajelske (Mt 10,23); Sin on čovičaski] onb Sinb človičaski (Mt 16,13). ${ }^{48}$

\subsubsection{Izricanje posvojnosti za treće lice}

Genitivni oblik lične zamjenice za treće lice kojim se izriče posvojnost prelazi iz postpozicije u glagoljičkome izdanju u antepoziciju u ćiriličkome $\mathrm{u}$ primjerima hudobno sr'ce nih] njih 'hudobno s'rce (NT1: 58); zapovid'nêga] njega Zapovid' (NT2: 40); po delih' nêga] po njega delihs (NT2: 54); $k$ pravadnosti nêga] $k$ njega pravadnosti (NT2: 60); Bogu njih'] njih' Bogu (NT2: 117). ${ }^{49}$ To bi moglo upućivati na opću težnju za uspostavom takva redoslijeda u nesročnim imeničkim sintagmama ovoga tipa u kojemu bi neobilježeni položaj zamjeničkoga oblika bio antepozitivan.

\footnotetext{
${ }^{47}$ U Tabli za dicu iz 1561. tek je jedna razlika ovoga tipa između glagoljičkoga i ćiriličkoga izdanja, s tim da se antepozicija pridjevskoga atributa iz prvoga mijenja u postpoziciju u drugome izdanju: ove artikule] artikule ove u primjeru potom ove artikule ili členi karstianske vêre ovdi zapisane napamet z redoa(!) [redom] govoriti naučite (DAMJANOVIĆ 2007: 52). Gordana Čupković navodi da u glagoljičkome Katekizmu iz 1561. atribut prethodi imenici (ČUPKOVIĆ 2010.a: 219). U hrvatskome staroslavenskom jeziku pridjevski atribut obično dolazi u postpoziciji, a njegova je antepozicija uvjetovana različitim čimbenicima, najčešće dodatnim isticanjem pridjeva (SUDEC 2013).

${ }^{48}$ Ovakav redoslijed pridjeva u višečlanim skupinama podudara se sa stanjem u hrvatskome staroslavenskom jeziku, gdje u cirkumponiranih pridjeva u postpoziciji dolazi onaj koji nije opisan (SUDEC 2013: 638).

${ }^{49} \mathrm{U}$ hrvatskome staroslavenskom jeziku zamjenica obično dolazi iza imenice, ali može doći i ispred, iako rjeđe (HCJ 2014: 315).
} 


\subsubsection{Redoslijed sintaktičkih jedinica}

Ćiriličko se izdanje od glagoljičkoga ponegdje razlikuje u redoslijedu članova rečeničnoga ustrojstva. U primjerima ne more moi Učenik biti] ne more biti moj Učenikb $(\mathrm{Lk} 14,26)$ predikatni proširak pomiče se iza predikata, a isto čini objekt u primjerima $z$ ovu pravu Veru hoteju ${ }^{50}$ ] hoteju z ovu pravu Veru (NT2: 51); na znan'je daje] daje na znanbje (NT2: 71). U primjeru I ovo kad reče, izdahnu] I kadb ovo reče, izdahnu (Lk 23,46) objekt se pomiče između subjunktora i predikata zavisne rečenice. Predikat dolazi na prvo mjesto zamjenom redoslijeda s priložnom oznakom (mjesta) u primjeru $v$ otaino mesto ju stavi] postavitb ju va otaino mesto (Lk 11,33); odnosno s objektom u primjeru K GALATOM POSLANA BÊ. IZ RIMA.] POSLANA BE K GALATOM IZ RIMA. (NT2: 220). Primjeri ovu suprot'vam' dobrotu] ovu dobrot suprotb vamb (2 Kor 8,6); va onoi ka ot vas' jest' ljubavi k' nam'] va onoi ljubavi ka odb vasb jestb k namb (2 Kor 8,7); imaju ov' prieti Pavlov nauk] imaju prieti ov' Pavlov Nauk (NT2: 270, bilj.) ukazuju na tendenciju nerazdvajanja sročnoga atributa od njime određene imenske riječi drugim (istovrsnim ili raznovrsnim) rečeničnim članovima, u što se međutim ne uklapa i primjer Kako se i naučiste od' Epafrodita predragoga našega tovariša službe] Kako se i naučiste odb Epafrodita predragoga našega službe tovariša (Kol 1,7).

Različit redoslijed može biti posljedica isticanja drugoga rečeničnog dijela, što je ujedno i najbrojnija skupina primjera: jeda mu hoće zmiju za ribu dati] jesda (!) mu hoće zmiju dati za ribu (Mt 7,10); premora ISUS Učenike svoje da vlizu u plav] primora ISUS učenike svoje da u plavb vlizu (Mt 14,22); koi godire spozna mene pred ljudi] ki godi mene spozna predb ljudi $(\operatorname{Lk} 12,8)$; I odgovorivši reče njim ISUS] I odgovorivši ISUS reče njims (Lk 20,34); govori tebe Meštar] têbi govori Meštarb (Lk 22,11); Eto si učinjen zdrav] Evo si zdravb učinjens (Iv 5,14); I kada uzdvignu oči ISUS] I kada vbzdvignu ISUS oči (Iv 6,5); da se ne rasčini zakon' Moisejov] da se Moisejovb Zakonb ne rasčini (Iv 7,23); ne biše ošće dan Duh Sveti] ne biše ošće Duhb sveti danb (Iv 7,39); Kakono Otac zna mene] Kako zna mene Otac (Iv 10,15); i ne more se razoriti pismo] $i$ pismo se ne more razoriti (Iv 10,35); biše ga uskrisil ot mrtvih] biše ga od m'rtvihb skrisilb (Iv 12,17). Redoslijed sintaktičkih jedinica mijenja se i u primjeru Va Svitovnih' Gospodskih 'pravdah'ošće tako se govori] ošće se Va svitovnihb Gospodskihb pravdahb tako govori (NT2: 53), u kojemu može biti riječ ili o stilskome ujednačavanju s ostatkom teksta, gdje su brojne konstrukcije koje počinju prilogom, ili pak opet o stavljanju naglaska na drugi rečenični dio, odnosno o subjektivnoj stilizaciji teksta.

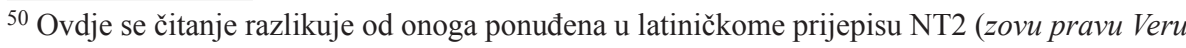
hote ju).
} 
Drugo sintaktičko rješenje odabrano je i u primjerima kad budete vidêli ova da se čine] kadb budete vidêli da se ova čine (Lk 21,31); Nego grêh', da očitovan'bude grêh'] Nego da Grêhb očitovanı bude Grêhb (Rim 7,13).

Promjenu redoslijeda pratimo i u primjerima kad jeste zli] kadb zli jeste (Mt 12,34); Sin čovičaski hoće priti] Sinb človičaski priti hoće (Lk 12,40); kad videli budete Sina Človičaskoga] kadb budete videli Sina Človičaskoga (Iv 6,62); pravo jeste slobodni] pravo slobodni jeste (Iv 8,36); Duša moja zmućena je(st)] Duša moja jestb zmućena (Iv 12,27); v'zeta jest'] jestb v'zeta (NT2: 43); Kako jest pisano] kako pisano jestb (Rim 3,4); ka dana jest' nam'] ka je(stb) namb dana (Rim 12,6); jest' izvan 'têla] izvanb têla jestb (1 Kor 6,18); da Duh'. nêgov ohlajen' bi] da bê Duhb njegovb ohlajens (2 Kor 7,13); Hvala budi tada Bogu] Hvala tada budi Bogu (2 Kor 8,16). ${ }^{51}$ Kako je vidljivo iz nedosljedna redoslijeda pomoćnih glagola biti i htjeti u navedenim primjerima, ne može se govoriti o eventualnoj općoj tendenciji za postpozitivnim smještanjem pomoćnoga glagola radi oponašanja jedne od značajki tradiranoga liturgijskog jezika $^{52}$ u ćiriličkome izdanju u svjetlu njegova jezičnoga »arhaiziranja ${ }^{53}$

\section{3. »Sintaktička korektura«}

Pojedine sintaktičke razlike između glagoljičkoga i ćiriličkoga izdanja mogu se tumačiti rezultatom provođenja svojevrsne korekture na sintaktičkoj razini, pri čemu se može govoriti o ispravljanju propusta na razini padeža ili oblika, odnosno odabiru jasnijega sintaktičkog sredstva. ${ }^{54}$ Takve razlike mogu, ali i ne moraju nužno biti u vezi s predloškom, odnosno književnojezičnom koncepcijom kojoj se daje prednost u pojedinome izdanju.

Nominativna sintagma jedna beseda iz glagoljičkoga izdanja zamjenjuje se u ćiriličkome izdanju akuzativnom sintagmom jednu besedu u primjeru $I$ kada godê dve ili tri besedê za jednu, kako na strani videti hoćete, da svaki bude moći razumeti, jedna beseda, ili ime, po dva puta, i po tri izrečena $i$ pisana, da jedna drugu tl'mači] I kada godê dve ili tri besedê za jednu, kako

\footnotetext{
${ }^{51}$ Prema Gordani Čupković, u glagoljičkome Katekizmu iz 1561. atribut postpozitivno dopunjuje kopulu u imenskom predikatu (ČUPKOVIĆ 2010.a: 219).

${ }^{52} \mathrm{U}$ hrvatskome staroslavenskom jeziku particip i infinitiv u složenih glagolskih oblika najčešće dolaze ispred pomoćnoga glagola, no nije neobičan ni drukčiji redoslijed (HCJ 2014: 250-260).

53 Česti su i primjeri u kojima je razlika u redu riječi praćena i različitom uporabom naglašenoga i nenaglašenoga prezenta glagola biti, npr. koi h tebê poslani jesu] ki su k tebi poslani (Lk $13,34)$, no zbog njihove brojnosti ovdje ne donosim i takve primjere.

${ }^{54}$ Naravno, takav sud uvijek valja uzeti s dozom zadrške s obzirom na još uvijek nedovoljnu istraženost hrvatske povijesne sintakse, koja ne omogućuje da se prosudi s većom sigurnošću je li što ispravno ili pogrešno na sintaktičkoj razini u hrvatskome jeziku 16. stoljeća.
} 
na strani videti hoćete, da vsaki bude moći razumeti, jednu besedu, ili ime, po dva Puta, i po tri izrečena i pisana, da jedbna drugu t'lmači (NT1: 51).

Sintaktička razlika Bog' hoće ovoga $i$ ono (...) razoriti] Bog hoće ovoga $i$ onoga (...) razoriti $(1$ Kor 6,13$)$ posljedica je ispravljanja vjerojatnoga propusta u uporabi dijelnoga genitiva koji je u glagoljičkome izdanju izostao na očekivanome mjestu.

Alternacija finitnoga i nefinitnoga glagolskog oblika u primjeru ovi blagoslovljeni Isus Kristus [...] doli z nebes prišal na sa zali svit', tere na se človičastvo vazel, i pripovidal', čudesa činio, dal'se je mučiti, na treti dan'od smr 'ti uskrsnul, i potle nakon .40. dan vaspet' na nebo uzaide] ovi blagoslovlêni Isusb Kristus [...] doli z nebesb prišalb na sa zali svitb, tere na se človičastvo vazelb, i prodikovalb, čudesa činilb, dalb se je mučiti, na treti danb od Sm 'rti usk'rsnulb, i potle nakon .40. dan vaspetb na Nebo vzašalь (NT1: 59) upućuje na subjektivnu stilizaciju teksta, gdje izbor aoristnoga oblika naspram aktivnoga participa preterita drugog i nije neobičan imamo li na umu da je riječ o klimaksu duge rečenice o Isusu Kristu.

U dvama izdanjima Novoga testamenta gdjekad konkuriraju gerund i finitni glagolski oblik, što može ukazivati na nastojanje za ispravljanjem pogreške iz glagoljičkoga izdanja u ćiriličkome, no ne uvijek podjednako uspješno. U primjerima I kad ISUS pride u Petrovu kuću, videći njegovu punicu ležeći imejući ognjenicu (Mt 8,14); Odgovorivši tada njemu niki ot Pisac, rekuć (Lk $20,39)$ gerund iz glagoljičkoga izdanja zamijenjen je aoristnim oblikom (vide, rekoše) u ćiriličkome, a tako je i u primjeru Dva človika vhodeći va Tempal moliti, jedan Farisei, a drugi Očitnik (Lk 18,10), gdje je gerund zamijenjen finitnim glagolskim oblikom (aoristnim oblikom v'zidosta) jer nije bio prihvatljiv u funkciji glavnoga i jedinog predikata. Nasuprot tomu, u primjeru Vidivši tada Isus ljuctvo uzaide na goru, i budući sel. pristupiše $k$ neтu učenici njegovi. I otvorivši usta svoja učaše njih (Mt 5,1-2) aoristni oblik zamijenjen je gerundom pristupivši u ćiriličkome. Korekcija sintaktičkoga sredstva iz glagoljičkoga izdanja provedena je i u primjeru koi odgovorivši reče njim] koi otgovori reče njimb (Mt 19,4). Slično je u primjeru Odgovori ISUS i reče njim] Odgovorivši ISUS i reče njim (Iv 8,14), gdje se u ćiriličkome izdanju nastoji slijediti uobičajena rečenična struktura kojom se uvodi upravni govor, ali je pritom ostavljen sastavni veznik.

U primjeru A Bog se neće mastiti svrhu svoih izabranih] A neće li se Bogb mastiti svrhu svoihb izabranihb (Lk 18,7) uvedena je upitna čestica li u ćiriličkome izdanju radi osiguravanja veće jasnoće prijevoda. ${ }^{55}$

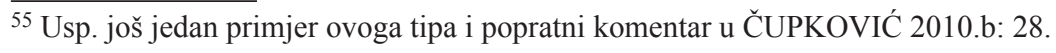




\section{UMJESTO ZAKLJUČKA: KAMO DALJE?}

Sintaktičke razlike između glagoljičkoga i ćiriličkoga izdanja Novoga testamenta nisu brojne, što pokazuje da ona nije bila temeljnom razinom književnojezičnoga uređivanja (barem ne izravno). Istraživanje je potvrdilo da valja odvojeno promatrati s jedne strane prvi dio glagoljičkoga izdanja, a s druge njegov drugi dio i ćiriličko izdanje. Dok se razlike među dvama izdanjima u drugome dijelu svode uglavnom na razlike u redu riječi, razlike u prvome dijelu brojnije su i raznorodnije te potvrđuju bolju usklađenost ćiriličkoga izdanja sa značajkama tradiranoga liturgijskog jezika.

Kao prioritet budućih istraživanja hrvatskoga protestantskog prijevoda Novoga testamenta nameće se pomno sravnjivanje obaju dijelova glagoljičkoga izdanja s pretpostavljenim predlošcima kako bi se sa sigurnošću mogle isključiti one razlike koje su uvjetovane predloškom od onih koje to nisu. Tako će se moći bolje razlučiti primarna i sekundarna razina (sintaktičkoga) redigiranja: prvoj je naime tekst bio podvrgnut prilikom »prenošenja« iz predloška (glagoljičko izdanje), a drugoj prilikom naknadna korigiranja prvotnoga prijevoda (ćiriličko izdanje). ${ }^{56}$ Ovim istraživanjem učinjen je tek korak prema boljemu poznavanju sintakse hrvatskih protestantskih izdanja, no zahvaljujući prikazanim razlikama može biti polazištem budućim istraživačima hrvatske povijesne sintakse za jasnije fokusiranje odabranih sintaktičkih tema u tome opsežnom korpusu.

\section{IZVORI}

Biblija. 1974. Zagreb: Kršćanska sadašnjost.

NT1 = DALMATIN, A.; S. KONZUL. 1562. Novi testament: 1. dio. Tübingen. (Latinički prijepis glagoljskog izvornika. 2013. Ur. D. Matak. Zagreb: Adventističko teološko visoko učilište - Filozofski fakultet Sveučilišta u Zagrebu - Školska knjiga.)

NT2 = DALMATIN, A.; S. KONZUL. 1563. Novi testament: 2. dio. Tübingen. (Latinički prijepis glagoljskog izvornika. 2015. Ur. D. Matak. Zagreb: Adventističko teološko visoko učilište - Filozofski fakultet Sveučilišta u Zagrebu - Školska knjiga.)

NTĆ = DALMATIN, A.; S. KONZUL. 1563. Novi teštament. Tübingen. (Pretisak. 2008. Ur. A. Jembrih. Zagreb - Ljubljana: Teološki fakultet »Matija Vlačić Ilirik« - Narodna in univerzitetna knjižnica.)

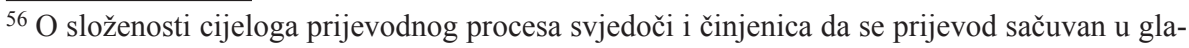
goljičkome autografu Stipana Konzula razlikuje i od varijante iz glagoljičkoga i od varijante iz ćiriličkoga izdanja. Usp. JEMBRIH 2007.a: 85-103.
} 


\section{LITERATURA}

BARBARIĆ, V.-T. 2011. Lajpciški lekcionar i njegovi »predlošci«. Rasprave Instituta za hrvatski jezik i jezikoslovlje XXXVII/1: 1-28.

BARBARIĆ, V.-T. 2012. Nove spoznaje o Lajpciškom lekcionaru. Rasprave Instituta za hrvatski jezik i jezikoslovlje XXXVIII/1: 1-18.

BARBARIĆ, V.-T. 2015.a. Nastajanje i jezično oblikovanje hrvatskih lekcionara u 15. $i$ 16. stoljeću. Doktorski rad. Zagreb: Filozofski fakultet.

BARBARIĆ, V.-T. 2015.b. Ranjinin lekcionar: ključ za predšesnaestostoljetne hrvatske lekcionare. Ricerche slavistiche LIX/13: 233-264.

BARBARIĆ, V.-T. 2016. Uloga Zadarskoga lekcionara u razumijevanju geneze najstarijih hrvatskih lekcionara. Croatica et Slavica Iadertina XII/1: 3-24.

BARBARIĆ, V.-T. 2017. Nastajanje i jezično oblikovanje hrvatskih lekcionara. Zagreb: Institut za hrvatski jezik i jezikoslovlje.

BIČANIĆ, A. (gl. ur.). 2011. Povijest hrvatskoga jezika. 2. knjiga: 16. stoljeće. Zagreb: Croatica.

BRATULIĆ, J. 1983. Pogledi hrvatskih protestanata na književni jezik. Radovi Zavoda za slavensku filologiju 18: 43-49.

BRATULIĆ, J. 1991. Lekcionar Bernardina Splićanina. J. Bratulić (ur.). Lekcionar Bernardina Splićanina 1495. Pretisak. Split: Književni krug - Zavod za znanstveni i umjetnički rad Hrvatske akademije znanosti i umjetnosti, V-XIX.

BUČAR, F.; F. FANCEV. 1938. Bibliografija hrvatske protestantske književnosti za reformacije. Starine JAZU 39: 49-128.

CEKOVIĆ, B. 2016. Grafematičke osobitosti glagoljičnog izdanja Artikula (1562). T. Kuštović; M. Žagar (ur.). Meandrima hrvatskoga glagoljaštva: Zbornik posvećen akademiku Stjepanu Damjanoviću o 70. rođendanu. Zagreb: Hrvatska sveučilišna naklada, $41-56$.

ČUPKOVIĆ, G. 2010.a. Jezik odlomka reformacijskoga glagoljskog Katekizma iz 1561. i glagoljaška književna tradicija. Čakavska rič XXXVIII/1-2: 209-226.

ČUPKOVIĆ, G. 2010.b. Književnojezična koncepcija glagoljskoga i ćirilskoga Novoga testamenta iz 1562./1563. Prilog proučavanju razlika. Filologija 55: 1-36.

ČUPKOVIĆ, G. 2013. Prilog proučavanju inojezičnih izvora hrvatskoga reformacijskoga prijevoda Novoga testamenta. Croatica et Slavica Iadertina IX/1: 137-144.

DAMJANOVIĆ, S. (prir.) 2007. Glagoljična i ćirilična »Tabla za dicu«. Pretisak. Zagreb: Hrvatska sveučilišna naklada.

DAMJANOVIĆ, S. 2014. Novi filološki prinosi. Zagreb: Matica hrvatska.

DAMJANOVIĆ, S. 2017. Uvod u filološku analizu protestantskih Artikula (1562). Kolo 1: 141-148.

ETEROVIĆ, I. 2016. Sintaktičke funkcije participa u hrvatskim protestantskim Artikulima (1562.). Rasprave Instituta za hrvatski jezik i jezikoslovlje XLII/2: 379-407.

FANCEV, F. 1916.a. Jezik hrvatskih protestantskih pisaca 16. vijeka. Prilog historičkoj gramatici jezika hrvatskoga ili srpskoga. Rad JAZU 212: 147-225. 
FANCEV, F. 1916.b. Jezik hrvatskih protestantskih pisaca 16. vijeka. Prilog historičkoj gramatici jezika hrvatskoga ili srpskoga. Rad JAZU 214: 1-112.

GOSPIĆ, A.; G. ČUPKOVIĆ. 2010. Književni i jezično-stilski aspekti glagoljske i ćirilske Table za dicu. A. Bjelčevič (ur.). Obdobja 27: Reformacija na slovenskem (ob 500-letnici Trubarjevega rojstva). Ljubljana: Znanstvena založba Filozofske fakultete, 303-321.

HCJ 2014 = GADŽIJEVA, S.; A. KOVAČEVIĆ; M. MIHALJEVIĆ; S. POŽAR; J. REINHART; M. ŠIMIĆ; J. VINCE. 2014. Hrvatski crkvenoslavenski jezik. Zagreb: Hrvatska sveučilišna naklada - Staroslavenski institut.

IVŠIĆ, S. 1967. Enklitike, osobito njihov namještaj u staroslovenskome jeziku s obzirom na ostale slavenske jezike. Rad JAZU 348: 61-140.

JEMBRIH, A. 1992. Još o jeziku Katekizma iz 1561. i 1564. Stipana Kozula (!) i Antuna Dalmate. Buzetski zbornik 17: 15-31.

JEMBRIH, A. 2007.a. Stipan Konzul $i » B i b l i j s k i$ zavod« u Urachu. Rasprave i građa o hrvatskoj knjižnoj produkciji u Urachu (1561. - 1565.) i Regensburgu (1568.). Prilog povijesti hrvatskoga jezika i književnosti protestantizma. Zagreb: Teološki fakultet »Matija Vlačić Ilirik«.

JEMBRIH,A. 2007.b. Pogovor uz pretisak glagoljičkoga Novoga testamenta (1562./1563.). A. Jembrih (gl. ur.). Novi testament 1562./1563. (pretisak). Zagreb: Teološki fakultet »Matija Vlačić Ilirik«, 5-82.

KUŠTOVIĆ, T. 2014. Jezik hrvatskog protestantskog ćiriličkog Novog zavjeta (1563.) prema hrvatskoglagoljskoj tradiciji. Filologija 62: 115-129.

KUŠTOVIĆ, T. 2016. Nepromjenjive riječi u protestantskim Artikulima. Ricerche slavistiche LX/14: 179-203.

KUŠTOVIĆ, T. 2017. Glagolski oblici u protestantskom izdanju Artikuli ili deli prave stare krstianske vere (1562.). Slovo 67: 91-112.

MATEŠIĆ, J. 1992. O literarno-lingvističkoj koncepciji hrvatskoga protestantizma. Buzetski zbornik 17: 11-14.

MIHALJEVIĆ, M. 2010. Položaj crkvenoslavenskoga jezika u hrvatskoj srednjovjekovnoj kulturi. I. Velev; A. Girevski; Lj. Makarijoska; I. Piperkoski; K. Mokrova (ur.). Zbornik na trudovi od Megjunarodniot naučen sobir »Sveti Naum Ohridski i slovenskata duhovna, kulturna i pismena tradicija« (organiziran po povod 1100-godišninata od smrtta na sv. Naum Ohridski). Skoplje: Univerzitet »Sv. Kiril i Metodij«, 229-238.

MILOŠ, I. 2016. Prijedlozi u čakavskome ekavskom dijalektu. Uvod u značenje. Zagreb: Institut za hrvatski jezik i jezikoslovlje.

POLOVIČ, I. 1908. Evangelij sv. Matevža v protestantskem glagolskem »Prvem delu Novoga Testamenta« iz 1. 1562. F. Ilešič (ur.). Trubarjev zbornik X. Ljubljana: Matica slovenska, 56-73.

RAMADANOVIĆ, E.; I. VIRČ. 2013. Redoslijed nenaglašenih sintaktičkih jedinica u kajkavštini. Rasprave Instituta za hrvatski jezik i jezikoslovlje XXXIX/2: 603-630.

SILIĆ, J.; I. PRANJKOVIĆ. 2005. Gramatika hrvatskoga jezika za gimnazije i visoka učilišta. Zagreb: Školska knjiga.

SUDEC, S. 2013. Položaj pridjeva u imenskoj skupini u hrvatskom crkvenoslavenskom jeziku. Rasprave Instituta za hrvatski jezik i jezikoslovlje XXXIX/2: 631-644. 
ŠAFǍ̌ÍK, P. J. 1865. Geschichte der serbischen Schriftthums. Prag: Verlag von Friedrich Tempsky.

VELA, J.; I. VRTIČ. 2013. Verborum ordo mysterium: Red riječi u Kašićevu prijevodu Biblije. Rasprave Instituta za hrvatski jezik i jezikoslovlje XXXIX/2: 645-673.

VIDIC, F. 1898. Nekaj o razmerju slovenskih Trubarjevih spisov k protestantskim hrvatskim knjigam. A. Bartel (ur.). Letopis slovenske matice za leto 1898. Ljubljana: Slovenska matica, 113-129.

VINCE, J. 2008. Uzmak genitiva izravnoga objekta. Slovo 56-57: 615-626.

VRTIČ, I. 2010. Apsolutni nominativ u hrvatskim svetopisamskim prijevodima. Zbornik Matice srpske za filologiju i lingvistiku 2: 35-48.

ZIMA, L. 1887. Ńekoje, većinom sintaktične razlike između čakavštine, kajkavštine i štokavštine. Zagreb: JAZU.

ŽAGAR, M. 2016. Grafetički postav glagoljičkog izdanja Artikula (Tübingen/Urach, 1562). T. Kuštović; M. Žagar (ur.). Meandrima hrvatskoga glagoljaštva: Zbornik posvećen akademiku Stjepanu Damjanoviću o 70. rođendanu. Zagreb: Hrvatska sveučilišna naklada, 585-606.

ŽAGAR, M. 2017. Elementi leksičkog odabiranja u izdanjima hrvatskih protestanata (Urach, 1561-1564): kontekst i metodološke pretpostavke. S. Botica; M. Malnar Jurišić; D. Nikolić; J. Tomašić; I. Vidović Bolt (ur.). Hrvatski prilozi 16. međunarodnom slavističkom kongresu. Zagreb: Hrvatsko filološko društvo, 213-224.

\section{Summary}

\section{Ivana Eterović}

\section{SYNTACTIC DIFFERENCES BETWEEN THE GLAGOLITIC AND THE CYRILLIC EDITION OF THE CROATIAN PROTESTANT TRANSLATION OF THE NEW TESTAMENT}

The Croatian Protestant translation of the New Testament has raised great interest in Croatian philology because of large differences in the language concept of its Glagolitic and Cyrillic editions, being thereby distinguished from other Croatian editions published in Urach's printing house. The largest interventions were recorded on the graphical and phonological levels, as well as vocabulary, to which the Croatian Protestants themselves paid the greatest attention, as we can observe from numerous prefaces to their published editions. Although they are not as numerous as differences on other linguistic levels, the syntactic differences between the Glagolitic and the Cyrillic New Testament (1562/1563) are also interesting. Therefore, it is exactly these differences that are analyzed in this article, as a contribution to the better understanding of the syntax of Croatian Protestant editions.

Keyw ords: Reformation, Croatian protestantism, 16th century, Bible, New Testament, Croatian translation, syntax 